\title{
The Relation of Kendang and Jaipongan: Functions and Inspirations of Kendang Musicality on Jaipongan's Journey
}

\author{
Asep Ganjar Wiresna ${ }^{1 \bowtie}$, Cece Sobarna ${ }^{1}$, Endang Caturwati ${ }^{2}$, Gugun Gunardi $^{1}$ \\ ${ }^{1}$ Universitas Padjajaran, Indonesia \\ ${ }^{2}$ Institut Seni Budaya Indonesia, Indonesia
}

Submitted: June 15, 2020. Revised: September 9, 2020. Accepted: November 24, 2020

\begin{abstract}
This study aims to describe the Kendang relationship, as a traditional Priangan musical instrument, to the Jaipongan performing arts and dance. Kendang, which has a central function in the Jaipongan dance performance, has received less appreciation in West Java arts' discourse. The Jaipongan dance art focuses on dance movements, although the song (gending) that accompanies the dance movement depends entirely on the Kendang music playing. This study used qualitative research methods. The data collection technique is done through interviews, observation, and document study. Data were analyzed through complete data collection activities and then adjusted the data and literature review, and in the end, described the research data. The results showed that Kendang, as a musical instrument has a relationship and attachment with the creation and development of the Jaipongan dance art. Kendang and the player (pengendang) have a vital function, in contrast to the stereotype that these instruments are only accompaniment to songs/dances in the performing arts. The Kendang instrument is an important part that regulates the tempo and the course of the Jaipongan dance performance. Pengendang, as artists and musicians, contribute greatly in communicating the performance of the performance both with dancers and the audience. Kendang is a source of inspiration for the creation of Jaipongan dance art. During the process of creating the Jaipongan dance, Gugum Gumbira acts as a creator communicating with other artists, both dancers, and pengendang.
\end{abstract}

Keywords: Kendang; Jaipongan; kendang musicality

How to Cite: Wiresna, A. G., Sobarna, C., Caturwati, E., \& Gunardi, G. (2020). The Relation of Kendang and Jaipongan: Functions and Inspirations of Kendang Musicality on Jaipongan's Journey. Harmonia: Journal of Arts Research And Education, 20(2), 126-134

\section{INTRODUCTION}

Kendang, a traditional musical instrument from West Java (Priangan), plays an important role, namely, as a reference to the beat in each song. Kendang is a symbol or representation of culture, used in the Priangan arts, one of which is the Jaipongan dance. Kendang's musicality in Jaipongan dance is different from other arts such as Bajidoran, Wayang Golek,
Tayub, and so on. Through the Kendang play, the identity attached to the performing arts and the locus (place) that is the development of the art can be easily identified. Jaipongan, an art that uses Kendang is a popular dance art form. Jaipongan is a dance art that was created since 1979, combining traditional dance and martial arts (pencak silat) from West Java (Durban, 2010). According to Durban, Jaipongan dance, in its current development, pre-

\footnotetext{
Corresponding author:

E-mail: asepganjarwiresna@gmail.com
} 
sents a variety of movements, music, and clothing and is displayed in local and international performances. Although the Jaipongan dance was born in Bandung, it is well known throughout the Priangan area. Jaipongan dance reached its peak of glory and popularity in 1980 (Durban, 2010). In its development, the Jaipongan dance is known throughout Indonesia and is performed in art events both locally and abroad.

According to Caturwati (2007), in contrast to other performing arts, Jaipongan was born in the modern era so that all aspects underlying this art can be found clearly. Aspects such as the origin of the character, timing, process, results of choreography, as well as the recording of gending accompaniment in Jaipongan can be found. Jaipongan is a representation of the dynamics of modern society towards performing arts. Jaipongan is a form of Gugum Gumbira's dissatisfaction, which is the creator of this dance against existing folk dances (Nalan, 2007). However, the Jaipongan dance is also a fragment of folk dance so that the folk-dance configuration is still present in the Jaipongan dance. According to Heriyani (2012), the source of the creation of Jaipongan dance is folk arts/dances such as Ketuk Tilu, Pencak Silat, Bajidoran, and Banjet. The Jaipongan dance repertoire has dynamic, attractive, and sensual dance movements. It is stated that sensuality and eroticization are elements that cannot be separated and the main attraction of Jaipongan dance. There are two sequences in the Jaipongan dance, namely the main movement sequence and the whole sequence. Jaipongan is a dance that has clarity and a systematic pattern. Dance and music movements are harmonized in the Jaipongan dance with each other to complement each other so that they become a harmonious whole.

Names such as Gugum Gumbira Tirtasonjaya and Tati Saleh are important and well-known figures in Jaipongan dance. Gugum Gumbira is the creator of Jaipongan and Tati Saleh is a prominent dancer. However, the literature on the art of Jai- pongan dance does not discuss the musicians/pengrawit as an essential part in the history of the development and preservation of this art. The birth and development of Jaipongan cannot be separated from the role and existence of musicians (nayaga) and Kendang instrument. For example, a singer named Suanda, in collaboration with Gugum Gumbira is a figure who has contributed in creating the works that will become known as Jaipongan. Suanda, as a skilled pengendang, is also known as a musician who dares to break out of tradition when accompanying Asikin (dancer and leader of Topeng Banjet Karawang). Suanda's expertise contributed to creating Jaipongan, which is a dance form that breaks out of the preceding traditional rules. It can be said that apart from choreographers and dancers, Kendang and musicians also have an important relationship with the existence of Jaipongan art.

Previous studies generally focused on the variety of Kendang's variety of tepak/ performance in Jaipongan, which is considered to have its characteristics. Tirwana (2017) in his writing, discusses how pengendang named Agus Supriyawan and Yayan Suryadi have different patterns. If Agus Supriyawan prefers to use tepak dasar bukaan jugala, Yayan Suryadi prefers to change tepak bukaan Jaipongan instead. According to Tirwana (2017), his research concludes that tepak Kendang in Jaipongan is something that can be developed but cannot be separated from its basic form and essence. Another study conducted by Saepudin (2013) explores the process of creating the Kendang Jaipongan tepak by Suwanda. This research examines the ideas, concepts, and methods used by a creator in creating tepak kendang jaipongan. This research is different from what has been done by previous researchers who have focused on the tepak kendang and a creator but tries to generally review the relationship of Kendang as a musical instrument and pengendang with the Jaipongan dance art.

This research is essential to do, considering the central function of the Kendang 
instrument in the creation and development of the Jaipongan dance, which, unfortunately, has not been discussed and reviewed much. Kendang and pengendang as artists and musicians should get the spotlight the same as the creators/choreographers, puppeteers, sinden/singers, and dancers get, considering the significant contribution to the arts of West Java, including the Jaipongan dance.

\section{METHOD}

This research uses qualitative research methods. In this case study, data collection techniques of the relationship between Kendang and the Jaipongan dance are interviews, observation, and document study. This study explores the relationship between Kendang and Jaipongan dance, and this art with the community through symbolic meanings. So, a qualitative research method is a method that is following the research objectives. Interviews were conducted with three Kendang musicians/pengendang named Oman Rohman, who came from Tasikmalaya, Mamat Rahmat, and Ido, who came from Soreang, Bandung district. Observations are made through activities such as watching the Jaipongan dance performance, training in playing Kendang, participating as a Kendang player in performances, and other significant and relevant activities in collecting data and information. Meanwhile, document study is carried out in order to complement research data and check the truth through literature reviews, which can be accessed online, in public libraries, and in private data sources/sources. Data were analyzed through qualitative stages such as complete data collection, sorting out relevant and needed data to answer research problems, matching the data found with existing references/literature, and describing the research results that had been processed into narrative sentences.

\section{RESULTS AND DISCUSSION}

The presentation of the relationship between Kendang and Jaipongan Dance is divided into several parts, namely (1) the relationship between Kendang and Pengendang; (2) Kendang in West Java Arts; and (3) Kendang and Jaipongan Dance.

\section{Kendang and Pengendang}

Kendang is waditra percussion made of wood, which is perforated in the middle, closed with dry skin, and tightened with ropes, tapped with palms and middle fingers. Rosidi (2000), Satjadibrata (2011), and Danadibrata (2009) define Kendang as an instrument or waditra which are equally defined as "gendang" in Indonesian. Kendang functions to regulate the rhythm of the song/gending, determine the song's rhythm, and create the song characteristics or gending. Kendang can be considered as an instrument that is dominant in the ensemble/performance of Sundanese Karawitan instruments.

Musical instruments are a form of art, which are created based on human taste and aesthetic value. Musical instruments are divided simply into two parts, namely waditra tradisi, a standard instrument, and waditra baru, a form of instrument developed and reconstructed. Musical instruments are manifested through tenacious thinking and a relatively long process so that they become a work that contains an accountable intellectual value. Kendang is a work of art that can be classified in waditra tradisi, which has been known for a long time by the people of West Java. In waditra Kendang, there are two circles on the top and bottom, nine binding holes (rarawat), nine binders (ali-ali), resonator holes (udel), and black and white outer and inner shells. There are two types of Kendang, namely Kendang Indung and Kendang Anak (Kulanter). Kendang is a musical instrument made of wood and played by tapping or beating using a Kendang drummer.

Sundanese Kendang usually uses the tones contained in the gamelan (pentatonic scale), namely ketiplak which has a high 5 tone (la, singgul), quotes that have a moderate 3 tone (), or that has a tone of $\mathrm{da}$, goods, and or which has 4 medium tones 
(ti, bem).

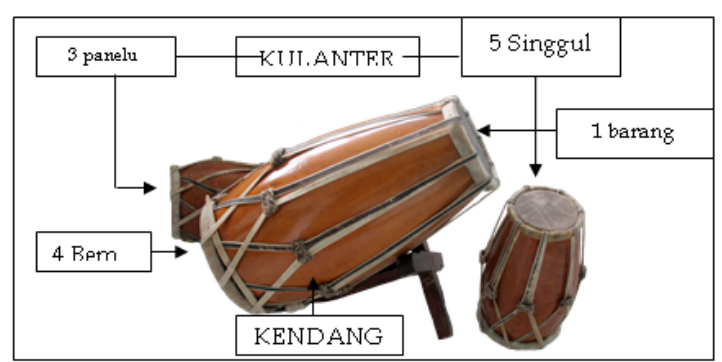

Figure 1. Kendang

Unlike the Javanese and Balinese Kendang, the Sundanese Kendang is placed on the left to the right or vice versa while lying straight/parallel in Java and Bali. The Sundanese Kendang is shaped the same as the Javanese Kendang and is different from the Balinese Kendang, which is formed straight without any indentation. One similarity between the Sundanese Kendang and the Jaipongan dance lies in the tendency to seem to break traditional idioms. Jaipongan dance is considered to 'violate' the generality of the graceful, gentle, and feminine traditional dance. Like the Sundanese Kendang, which is played more attractively and expressively. According to Oman the Sundanese Kendang was born in the Saka year during the Tarumanegara kingdom (Sundanese Kingdom).

Kendang is made from various natural materials; for example, to make $\mathrm{ku}$ luwung (resonator material), it should use jackfruit wood to make ancak from kananga wood, and the drummer should use chrysolite wood (Oman, interview, 2011). The use of these materials is not without reason, jackfruit wood, for example, is considered not easily cracked and has a distinctive golden yellow color. Munding, buffalo skin, is also used because it is strong and not hot for the pengendang hands. Even better, if the buffalo skin used is the skin of the calf that died in its mother's womb or it is usually called handalam. Bamboo is used as awi tali, generally sought from a flexible material, so it is not easily cracked. These materials are ideal materials used in making/producing Kendang.
However, in its current development, the production of Kendang Sunda has undergone adjustments in terms of material, function, and wasp pattern. This phenomenon causes the emergence of new pengendang, who have good skills and potential. However, the respect and appreciation for Kaditra Kendang began to decrease, such as sitting, pulling, and striding Kendang. It is not proper to do because Waditra Kendang is a source of livelihood that should be affixed with negative images and values. The behavior that does not respect and appreciate Waditra Kendang shows the thought that this musical instrument is not a valuable item. Waditra Kendang should be treated like western musical instruments such as guitar, drums, piano, bass, or cello that get special treatment from the artist. Traditional musical instruments should be parallel to western musical instruments because they have the potential to be recognized and compete in the international arena. The treatment of the new pengendang for Waditra Kendang is currently influenced by self-taught learning through audio-visual media without the presence of a teacher.

The presence of a teacher for pengendang is very important because it provides guidance and direction on the formation of potential, quality, and attitude. The teacher provides an understanding of the noble philosophical meanings and symbols of Waditra Kendang, based on the teacher's empirical experience. It is not easy to be a good pengendang because it takes skill and mastery of the material. According to Rahmat, who is a pengendang of the classical dance (interviewed on June 12, 2011, Bandung), the correct and upright sitting method for pengendang is a function of improving blood circulation. The beating technique that is carried out must produce a round sound, pengendang must adjust the power appropriately, as well as understand the character of the dance, song, dancer, and measure the quality of the pengrawit. Pengendang must also have spiritual provisions by doing tawasul, namely asking permission from God who he 
believes and respects his parents, teachers, ancestors, and himself. A pengendang named Ido (interviewed on June 14, 2011) stated that the clapping technique changed to slapping to produce a rounder sound. Contemplation accompanied by remembering the ancestors and teachers is believed to help pengendang and read the verses of the Koran, which are believed to increase the pengendang's self-confidence.

According to Pranoto (2013), the Kendang is a percussion instrument that functions to provide rhythmic accompaniment to the gamelan ensemble. Oktriadi (2017) defines pengendang as a pengrawit in a gamelan ensemble which is tasked with playing waditra kendang. Pengendang must have more musical knowledge than other pengrawit. The pengendang's task is to lead the musical presentation course, namely, to control the rhythm, tempo, and stop the performance. Knowledge of rhythm, tempo, songs contained in Sundanese musicals is the main asset for pengendang. If a pengendang does not own the basic knowledge, then the musical's aesthetic performance will not be adequately conveyed.

Oktriadi (2017) provides general descriptions of pengendang subjects who have special skills based on the locus of an institution in the arts, such as; Bah Rapi, Mamat Rahmat, to Yayan Supriadi. From the information presented by Oktriadi in the mention of these names, there are important notes related to the dynamics of kendang pengendang, one of which is the data that shows the regeneration journey of the pengendang subject in the same place as well as the same specialization but produces different creativity. According to Martopo (2006), creativity is a person's ability to change the old order into a new order. The three names above represent dynamic time, namely; 1960s, 1970s, until the pengendang subject representing the 1990s to the present, all of which show the dynamics of changing creativity in the play of Kendang, even though it is in a function of traditional art, such as; tayub and keurseus. There is an important point that pengendang creativity has occurred for a long time, and another important point that creativity occurs in the dimensions of a traditional performance.

The formation of identity as a pengendang requires a very long stage to cultivate a sense of self-confidence (Tawajuh). Tawajuh, according to Rohmat (interviewed on 12 June 2011) is a ripening process both physically and mentally, also known as "nyirepkeun". Through these stages, the pengendang will be able to release the energy that will be released through Waditra Kendang. Thus, the expected Kendang sound will come out. Through these stages, the pengendang can also control the concept of bodily recall - a momentary installation in a body frame that will be written on Waditra Kendang. This process also affects the level of awareness of pengendang to behave well.

\section{Kendang in West Java Art}

Kendang is a musical instrument that functions as a carrier of rhythm, tempo, and embat in both musical and dance arts. Kendang is very influential in the art of dance because it accompanies dance movements. Kendang also encourages the dancer's characteristics in performing a type of dance so that the performance can be interesting and enjoyable not only for dancers, musicians/pengendang, but also for the audience. Kendang is played differently in various dances so that the pengendang must understand and memorize each type of dance's musicality. For example, in Tari Topeng Klana Cirebon, there are clapping such as bango tong-tong, pring ketimpak, adu bapa, tumpak mobil Bandung, and so on. Kendang is played to accompany and create the nuances of Tari Topeng Klana Cirebon, a dance art depicting a Klana character who is known as a figure with bad character. The Kendang used in Tayub art is different, namely Kendang Kendor. The Kendang has to adapt to the various characters and different movements in Tayub art. Tayuban was started by using gending tataluan, which was in the form of instrumental songs; the music presented included: Gending Kebo Jiro, Bajeman, Watangan, 
Jipang Walik, Sarangan, Kaloran, Panglima, Gendu, Senggot and so on (Ramlan, 2003). The Kendang played in accompanying Tari Gatot Kaca also distinguishes it from other dance arts. In Tari Gatot Kaca, the technique used is bobot tepak, depicting the character of Ponggawa Lungguh, which is characterized by a dance that fluctuates.

The arts in West Java (Sunda) cannot be separated from Waditra Kendang, such as Wayang Golek, Wayang Wong Priangan, Sandiwara, Ketuk Tilu, Ronggeng Gunung, Ronggeng Amen, and Jaipongan. Kendang serves as accentuation in musicality towards the movements of people and puppets. Kendang also functions as a rhythm in channeling harmonization in the music performance. Moreover, Kendang provides aesthetic value and markers to the audience and communicates a type of art performance. In a traditional performance setting, the pengendang has fans or followers (related to the kendang performance pattern). The local community likes pengendang who are considered to have the ability, understanding of the Kendang Tepak treasury, as well as the pengendang relationship with the community. Kendang is closely related to the Priangan community and their arts. Kendang Sunda is found in almost all dance works ranging from puppet dances, folk dances, mask dances, New Creation Dances, and Contemporary Dances. Kendang is found in Sundanese arts, such as Gong Renteng or Kromong.

Kendang has a symbolization of sound in an art performance, which is interwoven as oral communication. For example, the sound tertektek in Bangreng art from Sumedang and pengendang sounds kuluwung (the resonator part of the Kendang) indicates that the dancer must tip to the pengendang. Another example is what happened in Ciamis Regency in the art of Ronggeng Amen, when the clapping pattern became mincid, the dancer's position became a big circle. The dancers follow the tempo performed by the Kendang instrument so that it can be said that the pengendang gives accentuation, so the dancer follows by filling in the dance movements.

\section{Kendang and Jaipongan Dance}

Gugum Gumbira as the creator of the Jaipongan dance is a composer and choreographer who often explores several arts types. Arts such as Ronggeng Amen, Topeng Pendul, Ronggeng Gunung, Bajidoran, Bangreng, Pencak Silat, and Ketuk Tilu. This affects the dynamic rhythm and complexity of Jaipongan dance art. Jaipongan became known and became very popular. According to Durban (2010), Jaipong reached its peak of popularity in 1980, so that both rural and urban communities favor this dance art. Jaipongan is favored by all groups, from the young to the older generation, from the lower middle class to the uppermiddle class. The existence of Jaipongan causes this dance art to be known in the country and in the international arena. Jaipongan is a popular dance art that is a breakthrough form of the development of performing arts. Jaipongan's popularity has made this dance as performance material for most art groups (Nuriawati \& Nalan, 2018), and even some art groups/communities that previously worked in other popular arts have switched to Jaipongan.

However, besides the popularity, existence, and progressiveness of Jaipongan, history has recorded that the role of musicality is only a small part of the dance art. There is even a stereotype that karawitan (music) is only an accompaniment to the Jaipongan dance art. This affects the existence and role of the underrated music in Jaipongan. This causes Kendang, as a musical instrument, to be not well known and favored by art connoisseurs or audiences. Kendang's appreciation and popularity follow from what the audience gives to dance/performance because this instrument is known only as an accompaniment to song and dance. This situation changed with the times and technology so that there was a collaboration between genres such as Jaz, Dangdut, and Pop. Kendang, as a musical instrument, was previously only known and focused on traditional space and installation [genre]. 
The fact is that there is an inherent attachment between Jaipongan dance and musical instruments that cannot be separated. Kendang is the most influential musical instrument in the Jaipongan dance because the tempo and dynamics are completely controlled in every Jaipongan dance movement by the Pengendang. There is a conception that the naming of Jaipongan is an onomatopoeia of the Kendang sound. In this context, sound and Kendang as an instrument represent music elements in Jaipongan (Aziz, 2007). It can be said that Kendang is the inspiration for the formation of Jaipongan art. The emergence of the Jaipongan dance by Gugum Gumbira, which was created in the city of Bandung inspired and influenced the performance of Kliningan Bajidoran in the Pantura area. The erotic movements of the Jaipongan dance and the attractive tepak Kendang have dominated the Kliningan Bajidoran show for up to ten years (Caturwati, 2011). This shows the attachment of the Kendang instrument, which has high progressivity, balanced and harmonious development in every development with the Jaipongan art itself. Jaipongan is the birth of a "new" dance movement that emerges from creativity, thus giving rise to new tepak Kendang musically. According to Saepudin and Haryono (2010), the creation of a variety of tepak Kendang Jaipongan that is new, original, and acceptable to West Java people shows the creativity and ability to play Kendang that is owned by the artist.

Durban (2010) explains that creating Jaipongan began when Gugum Gumbira discovered another type of Ketuk Tilu, with simple dance movements and energetic music. The attractive music, the voice of the singer, and the spontaneous rhythm of the gamelan player, as well as the joy and determination of the dancers, inspired him in creating the Jaipongan dance. It can be said that every element, including music in which there is Kendang, has an equal and central role in the creation of the Jaipongan dance art. The Jaipongan dance was then created into an art that was more dynamic and attractive than Ketuk Tilu. The move- ments of the arms and legs that are wider and alive are the advantages and differences that are found in the Jaipongan dance. According to Ratih (2001), the birth of relatively new dances has become a reality and demands of the soul who want the freedom of character, soul, and rhythm and escape from all forms of tradition. Jaipongan, which was born in the modern era, is an expression of the desire for freedom and releases the performing arts from the traditional standards and idioms that have long existed in people's lives.

In creating dance compositions, there is often a stagnation or deadlock in practice, so it is necessary to find an inspiration that can be drawn from the musical aspect. This confirms that there is a dependence on dance composition with a musical system and composition. Kendang and pengendang have a central position in the Jaipongan dance, for example the pengendang named Suanda creates many variations of the tepuk Kendang patterns and is elaborated with the Gugum Gumbira dance movements. Tepak Kendang, such as Bongbang, Oray Welang, Galeong, Mincid Keureup, and so on which are then widely used by other pengendang. Tepak is a term used in analogizing the Kendang punch in Sundanese musicals (Soepandi, 1995). Tepak can also be interpreted as a characteristic of a musician (pengendang) in playing Kendang, which is influenced by the ability and experience of the pengendang. Tepak Kendang was popular and used as a barometer in the development of other Tepak Kendang in around 1978, even today. According to Mamat Rahmat (interviewed on June 8,2019 ), the naming/terminology of the developing tepak Kendang name is a process of creativity in work. The name tepak Kendang becomes a communication sentence or symbol of meaning to preserve tepak Kendang Sunda.

The relationship between Kendang/Pengendang and Jaipongan is explained by Saepudin (2007) that the elements of improvisation of the tepak Kendang in the Jaipongan dance are very high. Jaipongan dancers, especially those who are pro- 
ficient and experienced, tend not to follow the tempo, movement, or variety of taps to communicate and sensitivity from a pengendang must occur. This reason also causes Jaipongan dancers to prefer to be accompanied by music and direct musicians, rather than only by audio/recording media. As a means of appreciation and entertainment, improvisation is an interesting side of Jaipongan dance. Kendang, who controls the musical instruments in the Jaipongan dance, then needs a pengendang who is observant of the dancers' improvisations so that the performance is successfully delivered. What is unique is that, through improvisation in the Jaipongan dance, new patterns or motifs in the Kendang Sundanese also emerge. The relationship between the two is a dynamic relationship that brings together the creation of new works in the performing arts. Creativity and development of the Jaipongan dance have occurred to date, affecting elements of music, choreography, clothing, and make-up (Nuriawati \& Nalan, 2018).

\section{CONCLUSION}

From the explanation above, it can be concluded three points about Kendang and Jaipongan dance. First, there have been several Kendang changes in terms of function, manufacturing materials, and pengendang ethics. Traditionally, Kendang is made with selected materials such as jackfruit wood and calfskin that died in its mother's womb (handalam) to create good musical instruments and produce quality sound. Pengendang as a player of this instrument, is required to have good ethics towards Kendang, such as not sitting and striding, and showing respect for Kendang as a musical instrument and a source of livelihood. Changes in Kendang production that do not meet the material requirements of choice have also reduced pengendang ethics for this instrument. The absence of the teacher for the pengendang also affects the attitude of the musicians towards Kendang. Meanwhile, the requirement to be a pengendang requires the ability to play mu- sic and spiritual acuity.

Second, Kendang is a musical instrument that plays a major role in the performing arts of West Java (Priangan). Arts such as Wayang Golek, Wayang Wong Priangan, Sandiwara, Ketuk Tilu, Ronggeng Gunung, Ronggeng Amen, or Jaipongan use Kendang as a carrier of rhythm and tempo. Kendang is an important element in both the traditional and contemporary realms, serving to provide a musicality and identity for each art type. Kendang is played differently in each performing art, adapting to various characters and dance movements. This marks the third conclusion from the above discussion.

Third, Kendang has a relationship in the process of creating the Jaipongan dance and the development of the art. During the process of creating the Jaipongan dance, Gugum Gumbira as the creator, communicated and discussed both with dancers and pengendang, marking the importance of dance movements and Kendang musicality in the art. Jaipongan dance is known as a new breakthrough in the traditional arts of West Java, which presents energetic and sensual female dance movements. The tepak Kendang Sunda that accompanies the Jaipongan dance is considered out of the traditional idiom, played with an attractive and expressive tepak pattern. Kendang has complete control over the tempo and rhythm of every movement in the Jaipongan dance. On the other hand, the Jaipongan dance gives rise to creativity and the creation of a variety of new, dynamic, acceptable, and even popular tepak Kendang by the people of West Java.

\section{REFERENCES}

Aziz, A. (2007). Pencugan Merupakan Kreativitas Tari Jaipongan, in Endang Caturwati, ed., Gugum Gumbira Dari ChaCha ke Jaipongan. Bandung: Sunan Ambu Press.

Caturwati, E. (2007). Tari di Tatar Sunda. Bandung: STSI Bandung.

Caturwati, E. (2011). Kajian Seni Pertunjukan. Bandung: STSI Bandung. 
Herdiani, E. (2012). Ronggeng, Ketuk Tilu dan Jaipongan; Studi Tentang Tari Rakyat di Priangan (Abad ke-19 Sampai Awal Abad ke-21). Bandung: Universitas Padjajaran.

Martopo, H. (2006). Paradigma Baru Penelitian Seni (The New Paradigm of Art Research). Harmonia Jurnal Pengetahuan dan Pemikiran Seni, 7(3), 125-132

Nalan, A. S. (2007). Gugum Gumbira: dari cha cha ke Jaipongan. Bandung: Sunan Ambu Press.

Nuriawati, R., \& Nalan, A. S. (2018). Kreativitas Gondo dalam Tari Jaipongan. Makalangan, 5(2).

Oktriyadi, R. (2019). Pengendang dalam Garap Karawitan Tari Sunda. Makalangan, 6(1), 29-36.

Pranoto, H. S. (2013). Sacrilegious Aspect of Javanese Gamelan: Past and Future. Harmonia: Journal of Arts Research and Education, 13(1).

Ramlan, L. (2013). Jaipongan: Genre Tari
Generasi ke Tiga dalam Perkembangan Seni Pertunjukan Tari Sunda. Resital Seni Pertunjukan, 14(1).

Rosidi, A. (2000). Ensiklopedia Sunda. Jakarta: Pustaka Jaya.

Ratih, E. (2001). Fungsi Tari Sebagai Seni Pertunjukan (The Function of Dance as A Performing Art). Harmonia Jurnal Pengetahuan dan Pemikiran Seni, 2(2)

Saepudin, A. (2013). Garap Tepak Kendang Jaipongan dalam Karawitan Sunda. Yogyakarta: ISI Yogyakarta.

Saepudin, A. (2013). Konsep dan Metode Garap dalam Penciptaan Tepak Kendang Jaipongan. Panggung, 23(1).

Saepudin, A. \& Haryono, T. (2010). Kreativitas Suwanda dalam Tepak Kendang Jaipongan di Jawa Barat. Yogyakarta: Universitas Gadjah Mada.

Tirwana, D. T. (2017). Kemprung Jaipong Penyajian Kendang dalam Jaipongan. Bandung: ISBI. 